\title{
Oximeter and BPM on Smartwatch Device Using Mit-App Android with Abnormality Alarm
}

\author{
Bedjo Utomo1, Syaifudin¹, Endang Dian Setioningsih¹, Torib Hamzah¹, Syevana Dita M. ${ }^{1}$, \\ and Parameswaran ${ }^{2}$ \\ ${ }^{1}$ Department of Electromedical Engineering Poltekkes Kemenkes, Surabaya Jl. Pucang Jajar Timur No. 10, Surabaya, 60282, Indonesia \\ ${ }^{2}$ Anna University, Tirunelveli, Tamilnadu, India \\ Corresponding author: Bedjo Utomo (e-mail: bedjoutomo123@gmail.com).
}

\begin{abstract}
Healthy condition is a parameter that is needed in life. One of the important parameters is the measurement of oxygen saturation in the blood and heart rate. The purpose of this research is to develop a Smartwatch SpO2 device and BPM sensor. This device is connected to WIFI using an Android Platform instead of using an LCD for parameter reading. This module design method uses the MAX30100 sensor to display the SpO2 and BPM values displayed on the OLED. Data processing is carried out using ATMEGA 328P programming and then displayed in the Android-based Mit-app application. The results show the average error for the SPO2 value is $0.868 \%$ and the standard deviation is $0.170 \%$, while the BPM value has an average error of $0.56 \%$ and a standard deviation of $0.30 \%$. The experiment results showed that the most significant error was $1.03 \%$, and the smallest was $0.62 \%$ for $\mathrm{SpO}_{2} \mathrm{ml} /$ hour with an accuracy of $0.05(0.57 \%)$ with a precision value of 0.08 at the selected speed of 50 $\mathrm{ml} /$ hour. Therefore, from the results, it can be concluded that the data can be displayed on OLED using the Mit-app Android application with an error rate accuracy of $0.57 \%$. This research design hoped that the device could facilitate the diagnosis of the condition of patients and health nurses.
\end{abstract}

INDEX TERMS Oximeter, Heartbeat Rate, At Mega328P, Smartwatch Android.

\section{INTRODUCTION}

Heart monitoring is essential because the body needs blood flow to all our organs.[1] Heart rate dramatically affects a person's health condition. The pacemaker rate is influenced by age and the human condition itself. The condition of children and adults has different heart rates and sick people and healthy people; by feeling the pulse, it can be seen a person's heart rate. Practitioners, doctors, or nurses usually use this method to determine the pulse. The calculation process is carried out within 15 seconds, and the result is multiplied by 4 to get the result of the number of heartbeats in 1 minute. This activity requires high concentration and requires equipment and time as a basis for calculation, so a nurse or doctor cannot do other work all the time. Along with the development of technology and information, monitoring heart rate can be done using direct or indirect techniques [2]. This is done directly by placing sensors on the heart itself, while indirectly by utilizing the flow of blood vessels, namely by tapping sensors on the blood flow [1][3]. Based on WHO data, people who have never done physical exercise will increase all causes of death by $20 \%-30 \%$ [4][3]. Physical activity will cause several changes in the body, such as oxygen levels in the blood. Under normal conditions, there is a storage of oxygen reserves in the blood; when doing these physical exercises, the body requires large amounts of oxygen to meet the needs for energy [4]. Oxygen will be taken up by the blood through the lungs and binds to hemoglobin. If the oxygen level in the blood decreases past normal limits, it will be hazardous for health because it can cause fainting and even death. The oxygen level in the blood bound to hemoglobin is called oxygen saturation ( $\mathrm{SpO} 2)$ [5]. Typical values for oxygen saturation levels range from $95 \%$ to $100 \%$. Several techniques can be done to measure oxygen saturation. One of them is by using oximetry. 


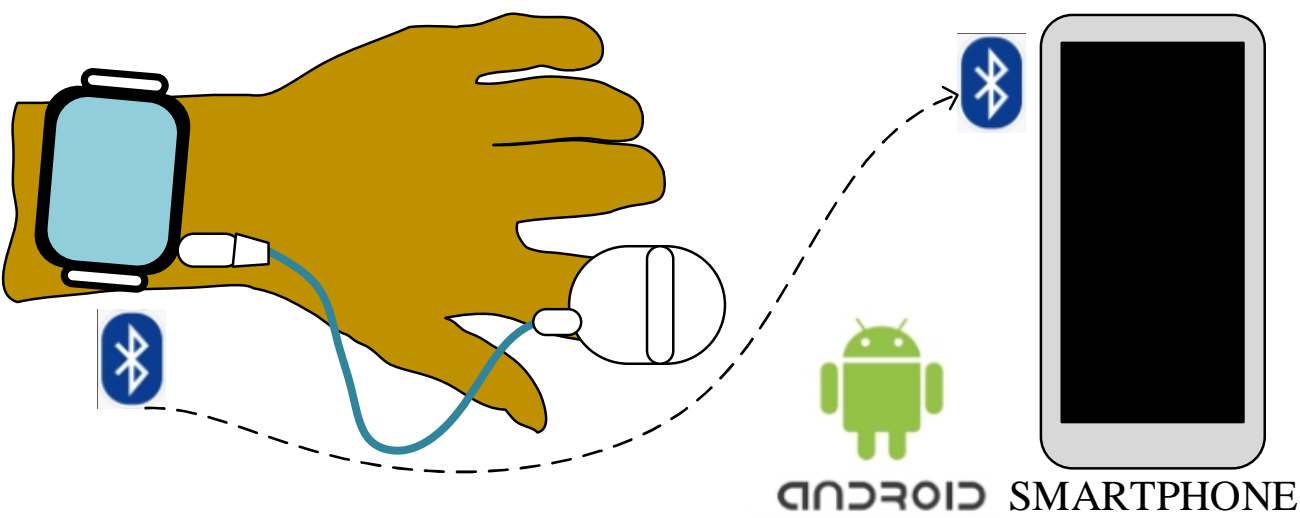

Front-end Application

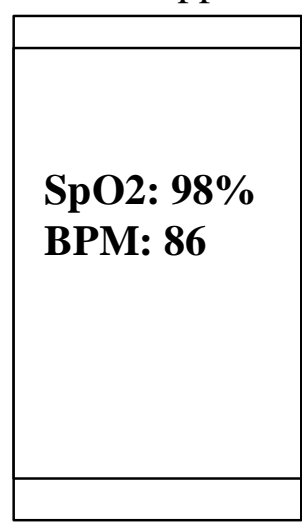

MIT-APP

FIGURE 1. Basic measurement of SpO2 and BPM using Android application

Pulse oximetry is a non-invasive continuous monitoring method of hemoglobin oxygen saturation (SpO2). Physical activity is any body movement that comes from skeletal muscles that require energy expenditure. The importance of hemoglobin function in the human body and a person doing the regular physical activity are interrelated. The relationship between a person's physical activity on hemoglobin levels is very close. It is proven that when a person performs a physical activity, such as exercise, there is an increase in high metabolic activity, the acid produced (hydrogen ions, lactic acid) also increases, resulting in a decrease in $\mathrm{pH}$ [5][6]. A low $\mathrm{pH}$ reduces the attraction between oxygen and hemoglobin. This causes the hemoglobin to release more oxygen, thereby increasing oxygen delivery to the muscles.

In this study, the author tries to find a solution to the problem, namely when someone does an activity not knowing whether the condition is normal or not, the author designs a spo2 and bpm detection tool that can be seen directly by the user and monitored remotely. Additionally, there is an SMS reminder to the user's family when the user is in an abnormal condition.

Along with the development of technology, several types of equipment have been developed. Yessy Mega Jayanti has developed BPM monitoring [13]. However, the device has not yet been equipped with remote monitoring and RTC patient data for every hour. Moreover, Lokeswara Darmalaksana developed a Portable BPM design with a finger sensor equipped with RTC and a storage SD card which aims to detect bpm by displaying data on seven segments [17]. Furthermore, Riszqy developed heart rate with a graphic LCD equipped with SD card storage and RTC. Furthermore, Fachrul Rozie designed an android-based pulse monitoring device. Still, it was limited to displaying one parameter. Another researcher Guruh Hariyanto also designed a digital oximeter based on the Atmega16 microcontroller to determine $\mathrm{SpO}_{2}$ levels, but it is still limited to one parameter and not portable.

Research on heart rate monitoring is still limited to designing tools using one parameter from several literature studies. Therefore, it is necessary to develop monitoring equipment that can monitor several sensor parameters related to vital signs. Further, the device can detect a person's health. Therefore, a new study is needed to design a device which able to monitor several sensor parameters. The design of the smartwatch model is the application of an application using a very simple Arduino 328P [7][8]. Therefore, this research aims to develop a BPM and SPO2 sensor Smartwatch with an android display [9].

Additionally, monitoring the condition of heart rate and Spo2 levels used a remote system based on Android users, which is equipped with SMS. This SMS is in the form of reminder notifications to patients. This device was equipped with Bluetooth communication so that doctors and paramedics would quickly take action if the patient were in an urgent situation.

\section{MATERIALS AND METHODS}

\section{A. RESEARCH DESIGN}

This study uses a Pulse Oximeter with the brand Puremed oxy-77 for data collection. Data is taken five times on five respondents.

\section{1) MATERIAL AND METHODE}

This study uses the Max30100 sensor as a Spo2 and BPM interceptor and RTC as a time display. [9] The display on this tool uses OLED as well as the MIT-app application as an application for Android [10]( FIGURE 1).

\section{2) EXPERIMENT}

At this stage, after the design is finished, testing the results of the Max30100 sensor readings. The reading results are compared to determine the measurement results.

\section{B. DIAGRAM BLOCK}

In the block diagram below ( FIGURE 2 ), the Max30100 sensor is used for $\mathrm{SpO}_{2}$ and BPM intercepts. RTC provides the date and time, and then the data is processed using At 
mega 328P, which later be displayed on the OLED and Bluetooth devices to send data to Android.

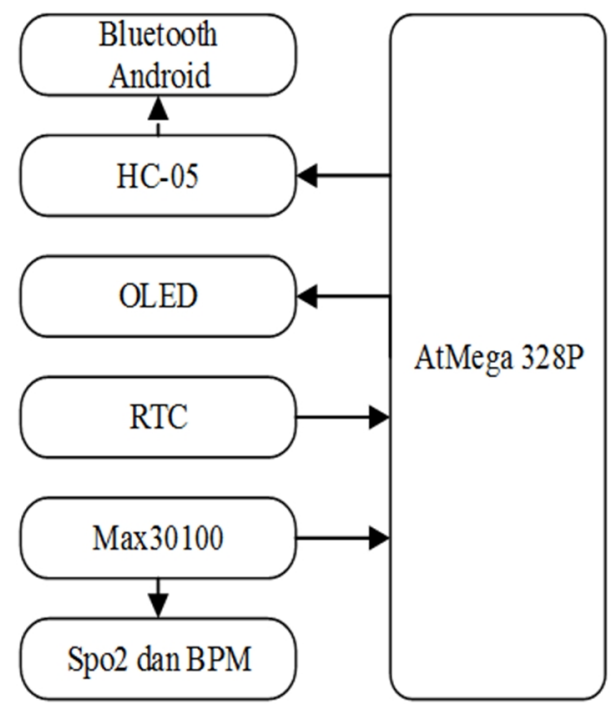

FIGURE 1. System Design Block Diagram

\section{1. $\operatorname{Max} 30100$}

Max30100 functions as a Spo2 and BPM interceptor [11][12]

2. RTC

RTC is used to display the time and clock, which will later be displayed on the display

3. OLED

OLED as a display that will display the results of the Max30100 and RTC sensors

5. Arduino ATmega 328P

Arduino ATmega 328 as a microcontroller

6. $\mathrm{HC}-05$

$\mathrm{HC}-05$ is Bluetooth which will later send data to android

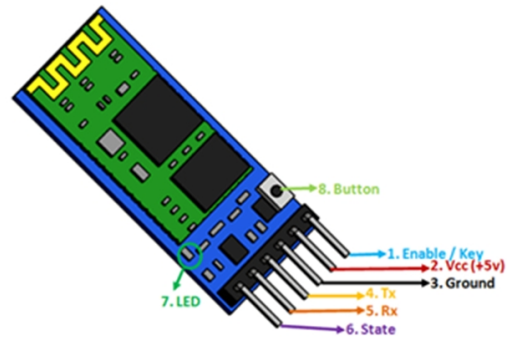

FIGURE 2. HC-05

In FIGURE 3, HC-05 is a module device for sending data wirelessly to android applications with a frequency of $2.4 \mathrm{GHz}$

\section{DIAGRAM FLOW}

In FIGURE 4, The flowchart at the start, the OLED will initialize, and at that time, the Max30100 sensor will start tapping, and the RTC is already running. Then the results will be displayed on the OLED screen, and the data results will be sent via the Bluetooth $\mathrm{HC}-05$ module to an Android mobile phone.

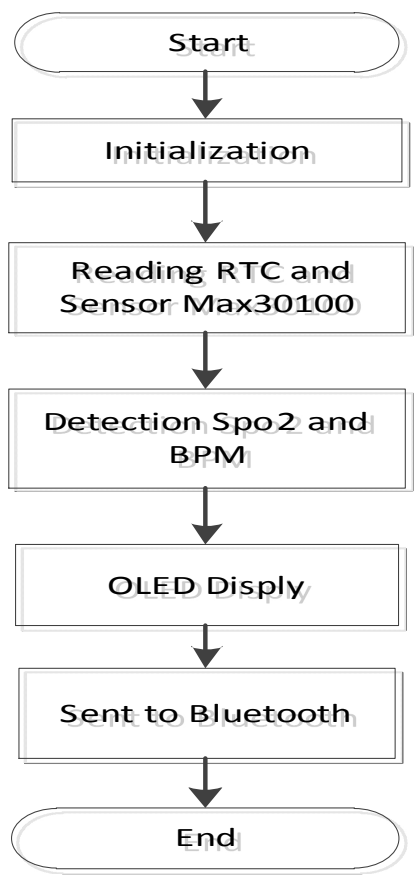

FIGURE 3. Flow Transmitter

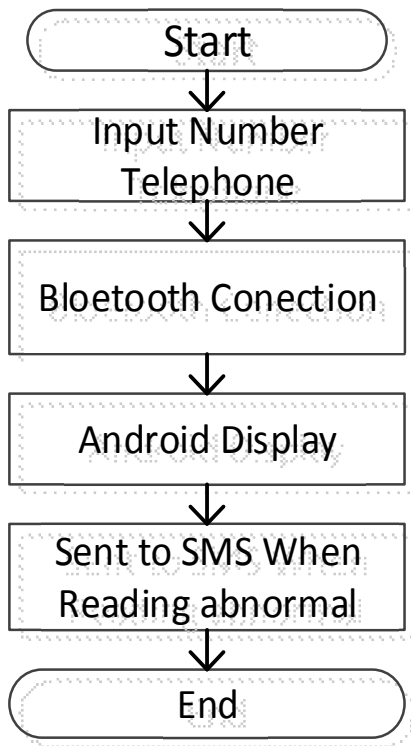

FIGURE 4. Diagram Flow Receiver

It is depicted when Bluetooth Android has been turned on, and then the data will be sent from the device to mobile phone Android via Bluetooth. If the sensor shows abnormal conditions, then the Android will send an SMS to the number that has been written when Bluetooth is on, Android will enter the telephone number. The data will be sent via Bluetooth and will be displayed on Android. If the conditions 
tapped by the sensor show abnormal conditions, Android will send an SMS to the number that has been written.

\section{CIRCUIT ANALOG}

An important part of this research is the analog circuit, as shown in FIGURE 5. This circuit is used to process all circuits, and then digital processing will be carried out using a microcontroller. A minimum system consists of an infrared photodiode sensor, ATmega $328 \mathrm{P}$ as a microcontroller, OLED as a display to show results. FIGURE 5 was a sensor used to connect the max30100 sensor with the minimum system circuit [13].

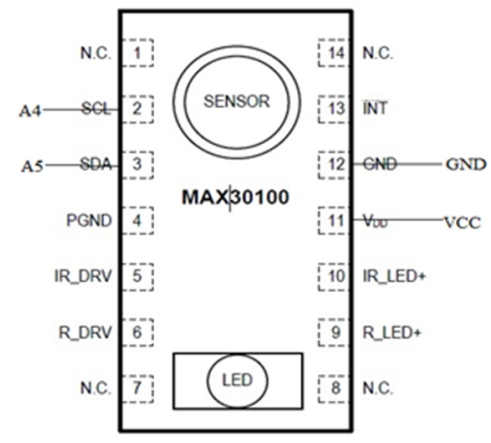

FIGURE 5. Circuit Max 30100

\section{RESULTS}

In this study, the Design of Smartwatch Spo2 and Bpm with Android Display has been compared using pulse oximetry Puremed Oxxy-77 to test performance (FIGURE 6). The results showed that the device, $\mathrm{SpO}_{2}$, and $\mathrm{BPM}$ smartwatch design with the android display were feasible. It is because the measurement results were still within tolerance limits.

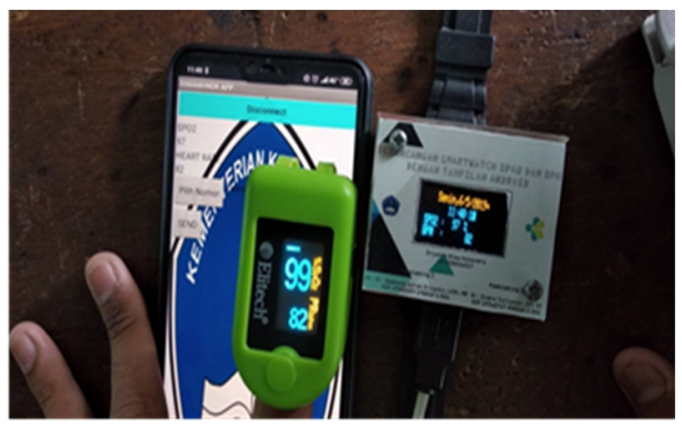

FIGURE 6. Process Compare With Original equipment

\section{1) SPO2 AND BPM SENSOR SMARTWATCH WITH ANDROID DISPLAY}

The Android display is shown in FIGURE 7. The digital part consists of the ATmega328 microcontroller, which is the controller and controller of the system. There are Max30100 and RTC sensors. RTC is useful for displaying the date and time, which will later be displayed on the OLED layer. There is an OLED as a display and HC-05 to send data to Android; then, on Android, the data is captured and displayed on the android layer, then the data is processed if the Spo 2 and Bpm are less than the settings it will send a message.

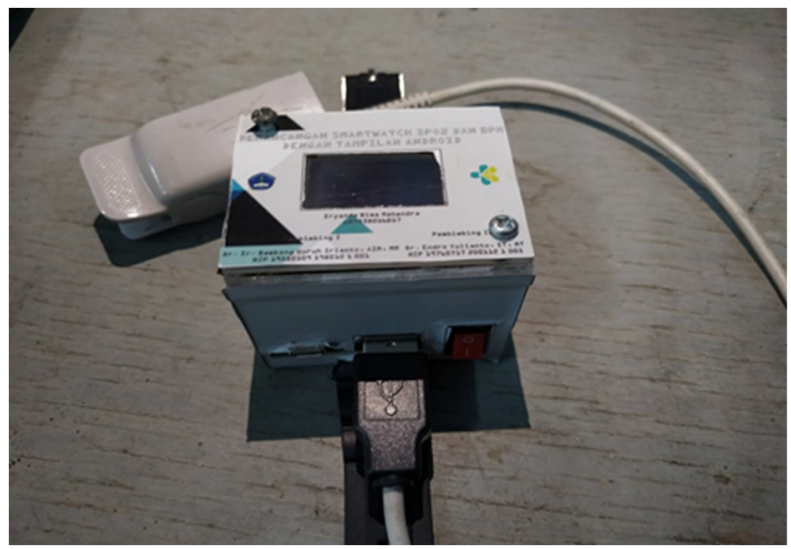

FIGURE 7. Design Modul

\section{2) LISTING PROGRAM ARDUINO}

The first time we turn on the tool, the OLED display will appear the name and title of this device.

\section{SNIPPED CODE 1. Reading sensor Max30100}

\begin{tabular}{|l|l|}
\hline 1. & LOOP: \\
2. & Serial.print("Initializing pulse oximeter.."); \\
3. & if (!pox.begin()) \{ \\
4. & Serial.println("FAILED"); \\
5. & for(;;); \\
6. & \} else \{ \\
7. & Serial.println("SUCCESS"); \\
8. & \} \\
9. & ENDLOOP \\
\hline
\end{tabular}

SNIPPED CODE 2. RTC reading and display data on OLED

\begin{tabular}{|l|l|}
\hline 1. & LOOP: \\
2. & display.setTextSize(1); \\
3. & display.setCursor(0, 17); \\
4. & display.print("SPO2 :"); \\
5. & display.setCursor(50, 17); \\
6. & //Serial.println ("SPO2"); \\
7. & \\
8. & display.print(pox.getSpO2()); \\
9. & display.setCursor(70, 17); \\
10 & display.print("\%"); \\
11. & pox.update(); \\
12. & display.setCursor(0, 25); \\
13. & display.print("BPM :"); \\
14, & //Serial.println ("BPM"); \\
& display.setCursor(75, 25); \\
15. & display.print(pox.getHeartRate(), 0); \\
16. & pox.update(); \\
17. & display.display(); \\
18. & display.clearDisplay(); \\
19. & tsLastReport = millis(); \\
20. & ENDLOOP \\
21. &
\end{tabular}


SNIPPED CODE 3. RTC, Spo2, and BPM reading and places the readings on the OLED

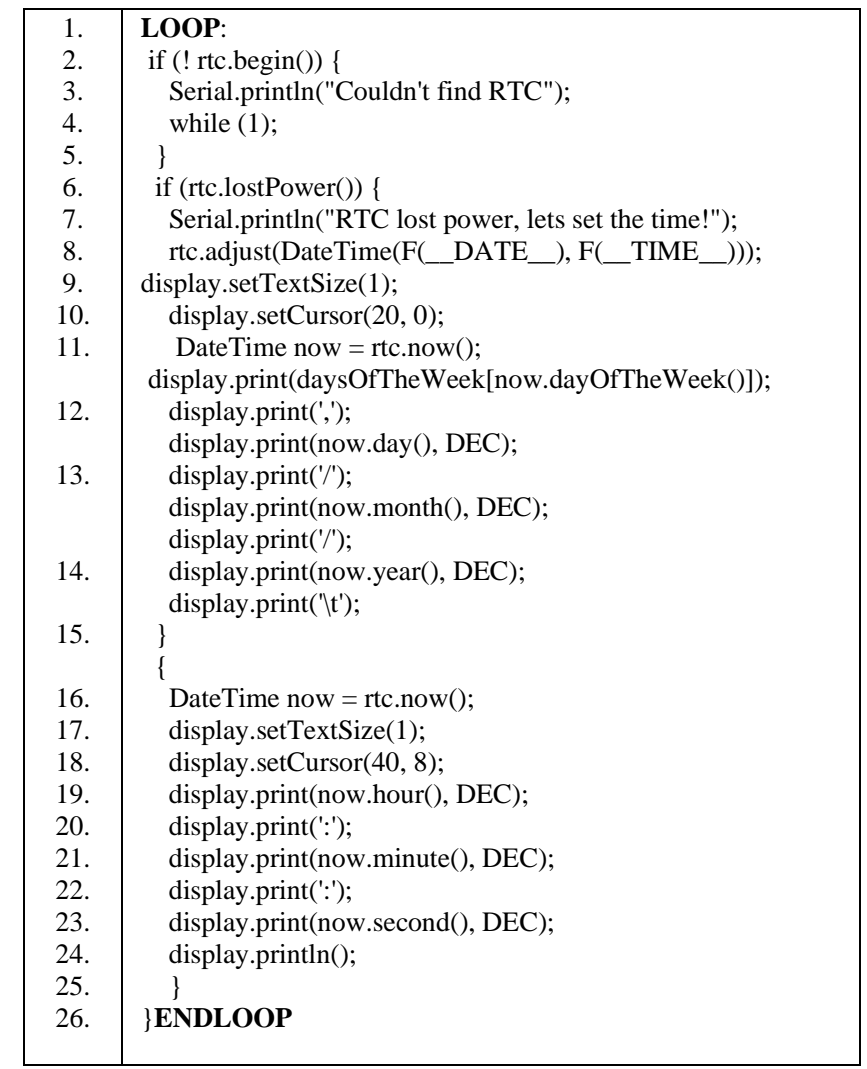

\section{SNIPPED CODE 4. send data via HC-05 to Android}

\begin{tabular}{|l|l|}
\hline 1. & LOOP: \\
2. & bpm=pox.getHeartRate(); \\
3. & spo=pox.getSpO2(); \\
4. & Serial.print("a"); \\
5. & Serial.println(bpm); \\
6. & Serial.print("b"); \\
7. & Serial.println(spo); \\
8. & ENDLOOP \\
\hline
\end{tabular}

In testing and measuring the ADC red and IR data through the serial plotter and serial monitor on the Arduino, there are graphs in FIGURES 8 and FIGURES 9.

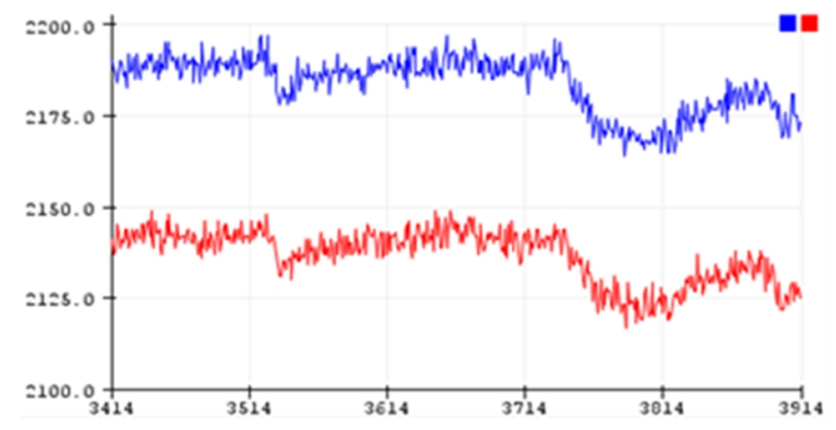

FIGURE 8. Plotter When Sensor Open
FIGURES 11 Shows the difference between the Red and IR ADC data at the open sensor position.

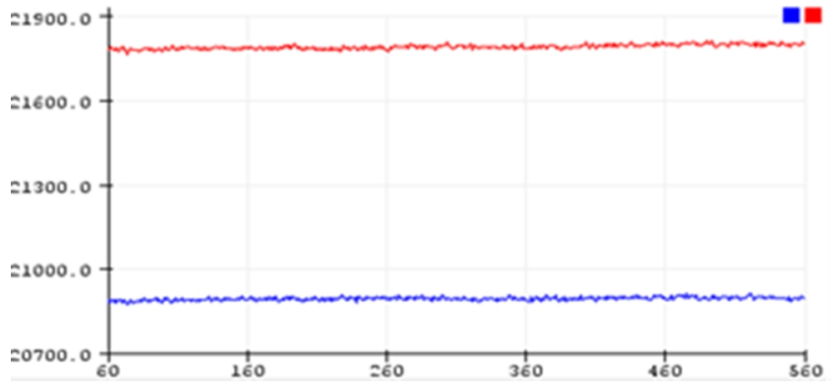

FIGURE 9. Plotter When sensor close

TABLE 1 shows the results of the comparison of measurements on the respondents.

TABLE 1.

Test results and error measurements

\begin{tabular}{lcc}
\hline \multirow{2}{*}{ Responden } & \multicolumn{2}{c}{ Error\% } \\
\cline { 2 - 3 } & SpO $_{2}$ \\
\hline Subject 1 & 0,83 & BPM \\
\hline Subject 2 & 0,83 & 0,47 \\
\hline Subject 3 & 0,62 & 0,56 \\
\hline Subject 4 & 1,03 & 0,27 \\
\hline Subject 5 & 1,03 & 0,45 \\
\hline Mean & 0,868 & 1,07 \\
\hline SD & 0,1709 & 0,564 \\
\hline
\end{tabular}

\section{DISCUSSION}

To find out the precision value of the design, we have to compare this device with a calibrated device. In this study, the researcher uses pulse oximetry Puremed Oxxy-77 to determine how much accuracy and precision the tool is made.

The results obtained on the average SPO2 comparison tool are 0.868 standard deviations of 0.170 , with the largest error range of $1.03 \%$ and the smallest $0.62 \%$. In contrast, the average BPM comparison is 0.564 , the standard deviation is 0.30 with the largest error range of 1.07 , and the smallest $0.27 \%$. And each sensor has an accuracy of $0.05(0.57 \%)$ and a precision value of 0.08 at the selected speed of $50 \mathrm{ml} / \mathrm{hour}$

\section{CONCLUSION}

The results of this study indicate that the $\mathrm{SpO}_{2}$ and BPM Smartwatch has an accuracy of $0.05 \%$ and 0.08 , respectively. Therefore, this device is still feasible to use. In the future, this research is expected to help patient care and health nurse in monitoring the patient's condition. Furthermore, this research can be developed more applicable and innovative in the case of technology-based health services. 


\section{REFERENCES}

[1] M. Erliyanto and S. S. Ir, "Perancangan Perangkat Monitoring Denyut Jantung ( Heart-Beat Monitoring ) Dengan Visualisasi Lcd Grafik Berbasis Atmel At89C51," Konf. Nas. Sist. dan Inform., pp. 294-299, 2008.

[2] F. Rashid and A. Khalid, "Design and Implementation of Real-time Electrocardiogram Monitoring System for Telemedicine Services," no. May, 2019, doi: 10.17485/ijst/2019/v12i16/141689.

[3] M. A. Pertiwi, I. D. Gede Hari Wisana, T. Triwiyanto, and S. Sukaphat, "Measurement of Heart Rate, and Body Temperature Based on Android Platform," Indones. J. Electron. Electromed. Eng. Med. informatics, vol. 2, no. 1, pp. 26-33, 2020, doi: 10.35882/ijeeemi.v2i1.6.

[4] R. H. Simanjuntak, J. N. A. Engka, and S. R. Marunduh, "Pengaruh Latihan Fisik Akut Terhadap Saturasi Oksigen Pada Pemain Basket Mahasiswa Fakultas Kedokteran Unsrat," J. e-Biomedik, vol. 4, no. 1, pp. 20-24, 2016.

[5] M. W. E. Tirajoh, J. F. Rumampuk, and F. LIntong, "Pengaruh Minuman Berkadar Oksigen Tinggi Terhadap Saturasi Oksigen Pada Olahraga Lari," J. Kedokt. Klin., vol. 1, no. 1, pp. 76-82, 2016.

[6] A. H. Sinambela, A. P. Tarigan, and P. Pandia, "Pengaruh Latihan Fisik Terhadap Saturasi Oksigen pada Penderita Penyakit Paru Obstruktif Kronik Stabil,” vol. 35, no. 3, 2015.

[7] S. Järvinen, "Design and development of a multi-sensor hardware platform for biomedical muscle monitoring." aaltodoc.aalto.fi, 2020.

[8] S. Das, "Development Of a Respiration Rate Meter - A Low - Cost Design Approach," Int. J., vol. 2, no. 2, 2013, doi: 10.5121/hiij.2013.2202.

[9] B. Utomo, Triwiyanto, S. Luthfiyah, U. Mudjiono, and T. Hamzah, "The Real-Time Vital Sign Monitor for Heart Rate and SPO2 Parameter Using Internet of Things Technology," J. Phys. Conf. Ser., vol. 1373, no. 1, 2019, doi: 10.1088/1742-6596/1373/1/012028.

[10] R. Meier, Professional Android 2 Application Development. Seriously, this book could have been so much better. Yes, it covers much of the ground you need to cover to get up and running with android development. But it is not very good for (a) diving in like a cookbook: too many examples cross multi-chapter bound, 2010.

[11] E. Y. Suyanti, "Rancang Bangun Deteksi Detak Jantung Manusia dengan Metode Pulse Sensor Berbasis IoT (Internet of Things) rancang bangun deteksi detak jantung manusia dengan metode pulse sensor berbasis iot (internet of things)," J. Tek. Elektro, vol. 8, no. 1, pp. 191-198, 2019.

[12] A. S. Hyperastuty and Y. Mukhammad, "Monitoring Saturasi Oksigen Menggunakan SPO2 MAX 30100 Berbasis Android Oxygen Saturation Monitoring Using Android-Based Spo2 Max 30100," vol. 2, no. 1, pp. 1-6, 2021.

[13] R. Frontini, P. Sousa, M. A. Dixe, R. Ferreira, and M. C. Figueiredo, "Designing a mobile app to promote healthy behaviors and prevent obesity: analysis of adolescents' preferences," Informatics Heal. Soc. Care, vol. 00, no. 00, pp. 1-15, 2020, doi: 10.1080/17538157.2020.1725766. 